\title{
Morphological diversity of fish along the rio das Velhas, Minas Gerais, Brazil
}

\author{
Nara Tadini Junqueira ${ }^{1}$, Cecília Gontijo Leal' ${ }^{2}$, Carlos Bernardo Mascarenhas Alves ${ }^{3}$ and \\ Paulo Santos Pompeu ${ }^{1}$
}

The rio das Velhas, located in central Minas Gerais State (Brazil), is a major tributary of the rio São Francisco. Despite several anthropogenic pressures, this basin supports more than 115 fish species. The aim of this study was to compare the morphological space occupied by fish assemblages in four regions (headwaters, upper, middle, and lower course) along the channel of the rio das Velhas. We try to answer the following question: Is there a change in the morphological organization of the fish along the longitudinal gradient of the river? Individuals from 67 species, collected at several sites in the basin from 1999 to 2008, were measured for 11 morphological attributes related to swimming behavior and habitat use. Through the graphs, the first two dimensions of the PCA suggest that the morphological volume occupied by the headwaters region is smaller than the other sections, because of the low richness of the site. However, morphological hypervolumes of the four reaches analyzed by Euclidean distances were not statistically different. The results indicated that only the density of morphological types increases along the rio das Velhas, and there is no difference between the headwaters and upper courses. Therefore, in order to use functional groups related to the morphology of the species as tools to take measures for the conservation and revitalization of the rio das Velhas, it is necessary analyze the density of species within these groups, as well as their composition.

O rio das Velhas, localizado na região central do estado de Minas Gerais (Brasil), é o mais extenso tributário do rio São Francisco. Apesar dos inúmeros impactos antrópicos que sofre, sua bacia abriga uma rica ictiofauna, com mais de 115 espécies conhecidas. O objetivo deste estudo foi comparar o espaço morfológico ocupado pelas assembleias de peixes em quatro regiões (cabeceira, alto curso, médio curso e baixo curso) ao longo da calha do rio das Velhas. Procuramos responder a seguinte pergunta: há uma mudança na organização morfológica da comunidade de peixes ao longo do gradiente longitudinal do rio? Indivíduos de 67 espécies, coletados em diversos trechos da bacia entre 1999 e 2008, foram medidos considerando 11 atributos morfológicos relacionados ao comportamento natatório e uso do habitat. Graficamente, as duas primeiras dimensões da PCA sugerem que o volume morfológico ocupado pela região de cabeceira é menor do que o dos demais trechos, devido à baixa riqueza do local. Entretanto, os hipervolumes morfológicos dos quatro trechos analisados por meio das distancias euclidianas não diferiram estatisticamente. Os resultados indicaram que apenas a densidade de tipos morfológicos aumenta ao longo do rio das Velhas, sendo que não há diferença entre a cabeceira e o alto curso. Portanto, para o uso de grupos funcionais relacionados à morfologia das espécies como ferramentas para tomada de medidas que visem à conservação $\mathrm{e}$ revitalização do rio das Velhas, é necessária a abordagem da densidade de espécies dentro destes grupos, assim como sua composição.

Key words: Community ecology, Ichthyofauna, Interspecific variation, Morphometry, rio São Francisco.

\section{Introduction}

Fish are among the most diverse aquatic biota, considering their morphology and ecology (Helfman et al., 2009). Their body shapes can be the results of evolutionary adaptations to environmental pressures (Gatz, 1979a; Watson \& Balon, 1984; Winemiller, 1991), especially food collection and hydrodynamic conditions (Matthews, 1998).
Morphological characters provide information about the ecological niches of fish (Winemiller, 1991), allowing inferences about the distribution of species (Watson \& Balon, 1984) and trophic patterns (Hugueny \& Pouilly, 1999). Specialized morphological characters also allow more efficient use of available resources, improving fitness and performance (Pianka, 1994). Thus, morphological attributes have been used as predictors of life habitats of fish (Keast \& Webb, 1966; Karr \& James, 1975).

${ }^{1}$ Universidade Federal de Lavras (UFLA), Laboratório de Ecologia de Peixes, Departamento de Biologia, 37200-000 Lavras, Minas Gerais, Brazil.naratadini@yahoo.com.br(NTJ)

${ }^{2}$ Universidade Federal de Lavras (UFLA), Programa de Pós-Graduação em Ecologia Aplicada, Laboratório de Ecologia de Peixes, Departamento de Biologia, 37200-000 Lavras, Minas Gerais, Brazil.

${ }^{3}$ Universidade Federal de Minas Gerais (UFMG), Nuvelhas- Projeto Manuelzão, Av. Antônio Carlos, 6627, Pampulha, 31270-901 Belo Horizonte, Minas Gerais, Brazil. 
Aquatic environments show great spatial variability in abiotic and biotic parameters (Lowe-McConnell, 1987). According to the River Continuum Concept (Vannote et al., 1980), rivers present a gradient of environmental conditions from upstream to downstream, resulting in water changes and increased availability of habitats. This is reflected as changes in fish assemblages and different studies show that these occur in a predictable manner along with longitudinal gradient of a river (Vannote et al., 1980; Gorman \& Karr, 1978; Peterson \& Rabeni, 2001; Ferreira, 2007). These authors focus primarily on changes in species richness and composition, but do not address the morphological changes of the fauna along the river.

Knowledge of morphological diversity of fish and functional aspects of morphology, particularly with regard to swimming behavior and habitat use, is critical to determining the functional organization of these assemblages (Mouillot et al., 2006; Tonn et al., 1990; Zobel, 1999). Nevertheless, in order to aid in planning measures to revitalize local impacts and implement conservation measures, it is necessary to understand how these aspects vary along a watercourse.

In this way, the objective of this study was to compare the morphological space occupied by fish assemblages in four regions along the channel of the rio das Velhas, in order to test the hypothesis that morphological space changes of the headwater toward the low course of the river. Alternatively, we tested the hypotheses that the morphological structure of fish assemblages remains in a longitudinal gradient.

\section{Material and Methods}

Study area. The rio das Velhas, located in central Minas Gerais State (Brazil), is the longest tributary of the rio São Francisco (CETEC, 1983). It is oriented in a southwest-northeast direction and extends $761 \mathrm{~km}$ from its headwaters, near the municipality of Ouro Preto at an elevation of $1,520 \mathrm{~m}$, to its confluence with the rio São Francisco, at an elevation of $478 \mathrm{~m}$. The estimated average annual flow is $300 \mathrm{~m}^{3} / \mathrm{s}$, with a drainage area of 29,173 $\mathrm{km}^{2}$ and mean width of $38.3 \mathrm{~m}$ (CETEC, 1983). The river crosses 51 municipalities and 4.5 million people (IBGE, 2000). The headwaters of the rio das Velhas are located in a transition zone between the Atlantic rainforest and "cerrado". Below its headwaters to its mouth, it flows only through "cerrado". Another vegetation formation occurs near high elevation headwaters: the "campos rupestres", or rocky shrublands. Currently, the upper rio das Velhas is highly degraded by pollution from the Belo Horizonte metropolitan area. Despite numerous signs of main stem impairment (Pompeu et al., 2005), the drainage of the rio das Velhas includes over 115 fish species identified in its main channel, tributaries and marginal lagoons.

Fish were sampled in the main channel and marginal lagoons of the rio das Velhas basin between 1999 and 2008 as part of ichthyofauna monitoring by the Manuelzão Project (Universidade Federal de Minas Gerais-UFMG). A total of 11 sites were sampled (Fig.1). The seven sites along the rio das Velhas main channel were located in the following municipalities, all in Minas Gerais State: RV-01 in São
Bartolomeu (20¹8'43”S 4334'01'W); RV-02 in Sabará (1954"15"S 4349'10"W); RV-03 downstream from lagoa Santa (19³1'50"S 43055'33"W); RV-04 near Santana do Pirapama

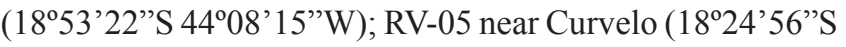

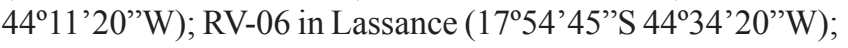
and RV-07 in Barra do Guaicuí (17 $14^{\prime} 47^{\prime \prime S} 44^{\circ} 49^{\prime} 16^{\prime \prime}$ 'W). The four marginal lagoons sites in the lower course of the river

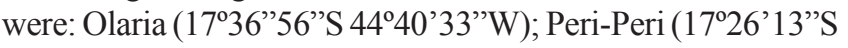

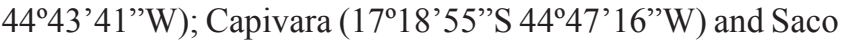

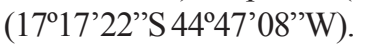

Data from the 11 sampled sites were combined into four reaches of the rio das Velhas: headwaters (RV-01); upper (RV02); middle (RV-03, RV-04 and RV-05); and lower (RV-06, RV-07 and marginal lagoons).

Fish sample. Fish were caught with gill nets ( 10 or $20 \mathrm{~m}$ long, 3 - to 16-cm stretch mesh), seines (5 $\mathrm{m}$ long and 1-mm mesh), cast nets (3-cm stretch mesh) and kick nets (1-mm mesh). Gill nets were armed in the water column for 14 h overnight, seines were used in shallow areas or littoral zones, kick nets were employed in near-shore aquatic macrophytes and in riffles, and cast nets were used in habitats too deep to wade. The three latter methods were employed for 1-3 $\mathrm{h}$ and data used only qualitatively to maximize the number of species collected. Stretches of 50-100 m were surveyed, depending on depth and water flow; all fish collected were fixed in $10 \%$ formalin solution and later transferred to $70 \%$ alcohol. Voucher specimens were deposited in the Museu de Zoologia of the Universidade de São Paulo (MZUSP).

Morphometric measurements. Morphometric data were obtained from ten individuals of each species, whenever this number of individuals was available. Only the adults were considered to avoid differences caused by ontogenic changes in body shape. Thirteen linear measurements and three area measurements were taken from each individual. Measurements were taken in a straight line, using a digital caliper $(0.01 \mathrm{~mm}$ precision for measurements up to $150 \mathrm{~mm}$ ). For measurements $>150 \mathrm{~mm}$, a plastic ruler (1.0 mm precision) was used. Fin length measurements were taken considering the longest fin ray and fin width measurements, considering the widest point with the fin extended. Body and fin areas were estimated from their contour outlined on millimetric graph paper. The body drawings, for area calculations, and body measurements were taken from the left side of each individual. These measurements were then converted into 11 morphological attributes, which are related to swimming behavior and habitat use. The values were expressed as means for each species. The following morphological attributes were considered according to Gatz (1979a, 1979b), and Watson \& Balon (1984) : compression index (CI): maximum body depth divided by maximum body width; relative depth (RD): maximum body depth divided by the standard length (SL); relative caudal peduncle length (RCPL): caudal peduncle length (distance from a vertical line at the level of the posterior margin of the base of the most posterior median fin to the terminus of the vertebral column) 
divided by the SL; caudal peduncle compression index (CPCI): depth of the caudal peduncle divided by the width of the caudal peduncle taken at the narrowest section; index of ventral flattening (IVF): average body height (vertical distance from midline to ventrum, midline defined as a imaginary line crossing the eye pupil towards the center of the ultimate vertebra) divided by the maximum body depth; relative pectoral fin area (RPFA): the area of the pectoral fin divided by the body area; pectoral fin aspect ratio (PFAR): length of the pectoral fin divided by its width; relative caudal fin area (RCFA): the area of the caudal fin divided by the body area (modified from Watson \& Balon, 1984); caudal fin aspect ratio (CFAR): the square of the fin depth divided by the caudal fin area; relative eye position (REP): the depth of the eye at midline

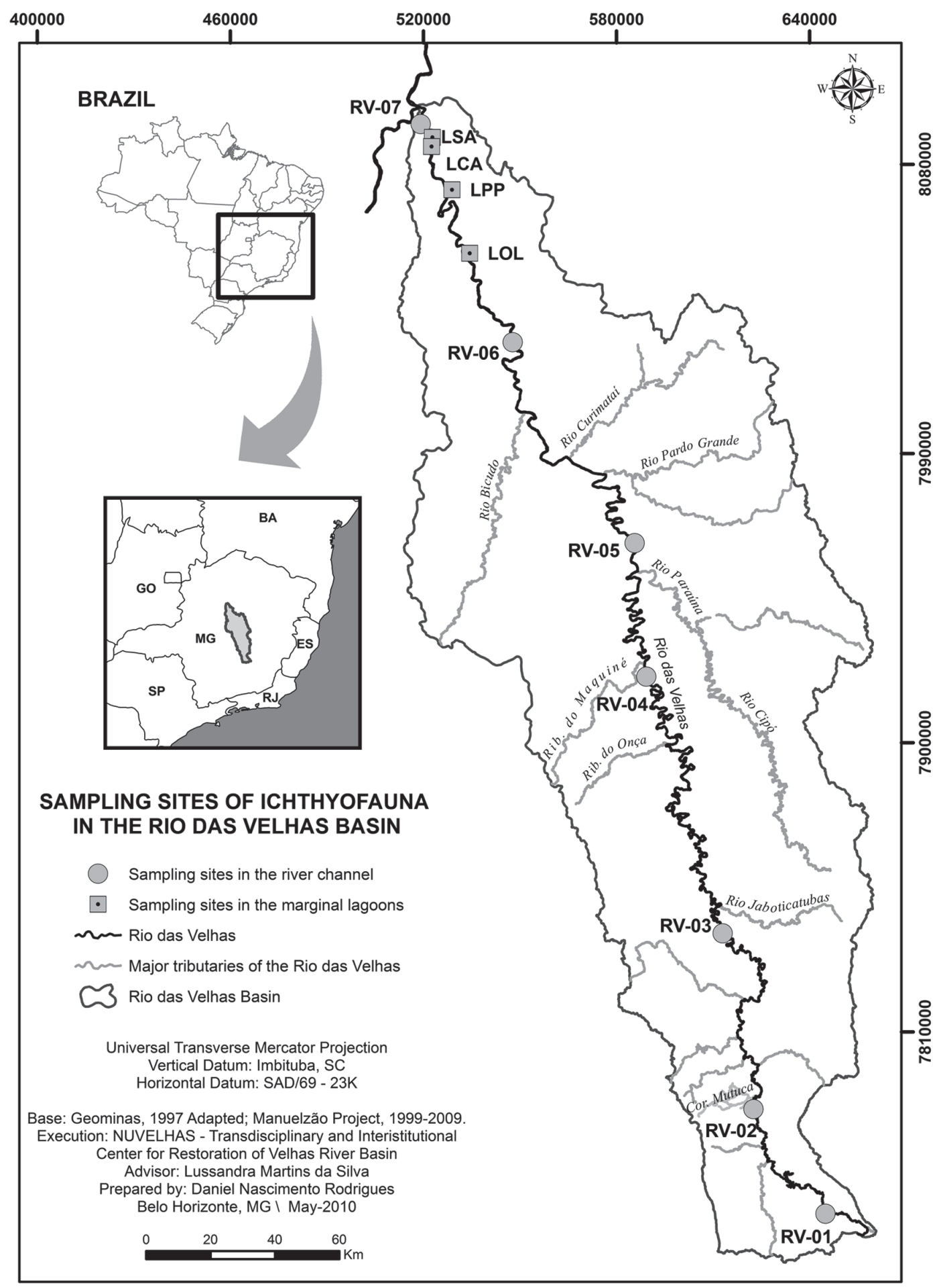

Fig. 1. Map of the rio das Velhas basin with locations of sampling sites. 
divided by the head depth; relative head length (RHL): head length divided by the SL.

Analysis. Species distribution in the morphological space was assessed using correlation-based Principal Component Analysis (PCA), considering mean morphological attributes of the species. This technique is a way to concisely analyze a large number of morphometric characteristics (Winemiller, 1991). Axes with an eigenvalue higher than 1 were retained for interpretation (Gatz, 1979a; Watson \& Balon, 1984). The analysis was performed using Statistica 6.0 (Statsoft, 2001).

For each reach assemblage, a normalized Euclidian distance matrix was constructed between the pairs of species from the ecomorphological attributes according to the following equation:

$$
D_{j k}=\left[\sum_{i=1}^{n}\left(x_{i j}-x_{i k}\right)^{2}\right]^{1 / 2}
$$

where $D j k$ is the Euclidian distance between species $j$ and $k$; $n$ is the number of attributes; and $x i j$ and $x i k$ are the values of attribute $i$ for the pair of species $j$ and $k$. In the case of normalized distance, the data were adjusted for the Gaussian distribution with a mean of 0 and a standard deviation of 1 :

$$
x_{i k}^{\prime}=\left(x_{i k}-\bar{X}_{k}\right) / \mathrm{DP}_{k}
$$

where $x i k$ is the attribute mean $k$ for the species $I ; X k$ is the mean for all $x i k$; and $\mathrm{SD} k$ is the standard deviation for attribute $k$. In each mirrored distance matrix, the distance of each species to the nearest neighbor (NND) was determined, which corresponds to the lowest value of each column. The mean of these NND values is the species dispersion index in morphological space (Ricklefs et al., 1981). The distance of each species to the centroid of its assemblage (DC) was calculated. In these calculations, the mean of each column represents the centroid of each species, and the mean of species centroids represents the assemblage centroid. The difference between these values is the distance of each species to the assemblage centroid (DC), and the mean of the DC values is an estimate of the relative size of the morphological hypervolume occupied by the community (Winemiller, 1991). The differences between the DC and NND means between reach assemblages were tested through ANOVA with Tukey HSD post hoc test using Statistica 6.0 software (Statsoft, 2001).

\section{Results}

Measured fish included 509 individuals, 67 species from 23 families, and 7 orders (Table 1). Three species were found in headwaters, 19 in upper course, 41 in middle course and 57 in lower course.

The first two axes of the PCA explained $57.28 \%$ of the data variation (Table 2). The first axis explained $38.77 \%$ of the variance (Table 2), and the attributes that most contributed were relative pectoral fin area (RPFA) and relative eye position (REP), with negative values and compression index (CI), relative depth (RD), caudal peduncle compression index (CPCI) and pectoral fin aspect ratio (PFAR) featuring positive values. Species with higher positive scores in the first axis show more depth and compressed bodies and longer pectoral fins, typical of nektonic species, such as Characiformes. At the other extreme of this morphological gradient, with lower negative scores, the species show large pectoral fins and dorsally located eyes, suggesting benthic species, such as Loricariidae catfishes. The second axis, accounting for $18.51 \%$ of the variance, had a higher positive contribution to relative caudal fin area (RCFA) and relative head length (RHL).

The species distribution in each reach in the two first axes of morphological space shows that species of upper, middle, and lower courses occupy a similar area, with a large overlap in assemblages, although different in size (Fig.2). The space occupied by the headwaters in the first two PCA axes is smaller than others. Considering the Euclidian distance measurements between pairs of species, the lower course occupied the largest morphological hypervolume because of its higher average distance to the centroid $(\mathrm{DC}=0.5)$. However, the means distances to the centroid of headwaters ( $\mathrm{DC}=0.3)$, upper $(\mathrm{DC}=0.49)$, middle ( $\mathrm{DC}=0.49)$, and lower $(\mathrm{DC}=0.5)$ course were not significantly different $\left(\mathrm{F}_{3.12}=0.33 ; \mathrm{p}=0.80\right)$. The species dispersion in morphological space was highest in the headwaters (1.95), followed by upper course (1.02), the middle (0.73), and lower course (0.71) (Fig. 3). These values were significantly different $\left(\mathrm{F}_{3.12}=4.82 ; \mathrm{p}=0.03\right)$, with headwaters different from the middle $(\mathrm{p}=0.007)$, and lower $(\mathrm{p}=0.006)$ courses.

\section{Discussion}

The distance to river mouth is an important predictor of the variation in assemblage composition, since the effects of flow regime and habitat are different between stream regions (Kennard et al., 2007). The progressive increase in the number of fish species from headwaters downstream is well known (Belliard et al., 1997; Ibanez et al., 2007), and richness has been predicted by altitude and stream order measurements (Bistoni \& Hued, 2002; Oberdorff \& Porcher, 1992). Species addition has been related to gradual increases in living space, habitat diversity and environmental stability downstream (Willis et al., 2005; Infante \& Allan, 2010). However, although a richness gradient is observed in the rio das Velhas, the hypothesis that the morphological space changes along the longitudinal gradient was rejected. The first two dimensions of the PCA suggested that the morphological volume occupied by the headwaters region is smaller than other sections, probably due to the lower richness of the site. However, morphological hypervolumes of the four reaches analyzed by Euclidean distances were not statistically different. The results indicated that only the density of morphological types increases along the rio das Velhas, and there is no difference between the headwaters and upper course. However, it is important to 
Table 1. Means values of 11 morphological attributes estimated for 67 fish species (abbreviations of morphological attributes are in the Material and Methods section) and species distribution along the rio das Velhas basin $(1=$ headwaters of the rio das Velhas; 2 = upper course of the rio dasVelhas; 3 = middle course of the rio das Velhas; 4 = lower course of the rio das Velhas).

\begin{tabular}{|c|c|c|c|c|c|c|c|c|c|c|c|c|c|c|c|c|}
\hline \multirow[b]{2}{*}{ Species } & \multirow[b]{2}{*}{$\mathrm{N}$} & \multicolumn{11}{|c|}{ Morphological attributes } & \multicolumn{4}{|c|}{ Occurrence } \\
\hline & & $\mathrm{CI}$ & $\mathrm{RD}$ & RCPL & CPCI & IVF & RPFA & PFAR & RCFA & CFAR & REP & RHL & 1 & 2 & 3 & 4 \\
\hline Acestrorhynchus britski & 4 & 1.83 & 0.17 & 0.11 & 1.87 & 0.56 & 0.03 & 3.76 & 0.16 & 0.87 & 0.69 & 0.28 & & & $\mathrm{x}$ & $\mathrm{x}$ \\
\hline Acestrorhynchus lacustris & 10 & 1.96 & 0.22 & 0.11 & 1.83 & 0.6 & 0.01 & 3.36 & 0.14 & 0.84 & 0.73 & 0.28 & & & & $\mathrm{x}$ \\
\hline Anchoviella vaillanti & 7 & 2.64 & 0.23 & 0.14 & 3.37 & 0.57 & 0.04 & 3.45 & 0.12 & 1.66 & 0.53 & 0.24 & & & & $\mathrm{x}$ \\
\hline Apareiodon affinis & 2 & 1.26 & 0.23 & 0.17 & 2.6 & 0.62 & 0.08 & 2.14 & 0.18 & 0.83 & 0.61 & 0.21 & & & $\mathrm{x}$ & \\
\hline Astyanax aff. scabripinnis & 10 & 1.94 & 0.29 & 0.16 & 2.54 & 0.57 & 0.02 & 2.89 & 0.13 & 1.61 & 0.62 & 0.26 & $\mathrm{x}$ & $\mathrm{x}$ & & \\
\hline Astyanax fasciatus & 10 & 2.89 & 0.32 & 0.11 & 2.56 & 0.53 & 0.03 & 4.47 & 0.14 & 2.48 & 0.59 & 0.27 & & $\mathrm{x}$ & $\mathrm{x}$ & $\mathrm{x}$ \\
\hline Astyanax lacustris & 9 & 2.59 & 0.39 & 0.12 & 3.77 & 0.59 & 0.03 & 3.23 & 0.13 & 0.77 & 0.57 & 0.23 & & $\mathrm{x}$ & $\mathrm{x}$ & $\mathrm{x}$ \\
\hline Astyanax taeniatus & 10 & 2.52 & 0.29 & 0.13 & 3.17 & 0.56 & 0.02 & 3.38 & 0.13 & 2.38 & 0.58 & 0.26 & & & $\mathrm{x}$ & $\mathrm{x}$ \\
\hline Australoheros aff. facetum & 3 & 2.03 & 0.48 & 0.11 & 6.39 & 0.57 & 0.1 & 3.61 & 0.1 & 0.89 & 0.63 & 0.37 & & & $\mathrm{x}$ & $\mathrm{x}$ \\
\hline Brycon orthotaenia & 9 & 2.56 & 0.33 & 0.14 & 3.14 & 0.59 & 0.03 & 4.01 & 0.14 & 0.51 & 0.6 & 0.24 & & & $\mathrm{x}$ & $\mathrm{x}$ \\
\hline Bryconamericus stramineus & 10 & 1.91 & 0.21 & 0.16 & 2.46 & 0.52 & 0.01 & 3.51 & 0.12 & 2.21 & 0.55 & 0.22 & & & $\mathrm{x}$ & $\mathrm{x}$ \\
\hline Bunocephalus spp. & 10 & 0.48 & 0.13 & 0.22 & 1.22 & 0.63 & 0.25 & 1.78 & 0.13 & 2.2 & 0.93 & 0.19 & & & $\mathrm{x}$ & \\
\hline Cephalosilurus fowleri & 4 & 0.64 & 0.17 & 0.14 & 2.53 & 0.56 & 0.1 & 1.63 & 0.23 & 0.32 & 0.87 & 0.29 & & & $\mathrm{x}$ & $\mathrm{x}$ \\
\hline Characidium zebra & 10 & 1.8 & 0.21 & 0.2 & 2.24 & 0.52 & 0.06 & 3.1 & 0.09 & 4.16 & 0.61 & 0.24 & & & & $\mathrm{x}$ \\
\hline Crenicichla lepidota & 7 & 1.57 & 0.25 & 0.13 & 3.06 & 0.6 & 0.06 & 2.19 & 0.12 & 0.59 & 0.76 & 0.35 & & & $\mathrm{x}$ & $\mathrm{x}$ \\
\hline Curimatella lepidura & 10 & 2.57 & 0.39 & 0.14 & 3.34 & 0.58 & 0.01 & 3.23 & 0.12 & 0.83 & 0.63 & 0.28 & & & & $\mathrm{x}$ \\
\hline Eigenmannia virescens & 10 & 2.69 & 0.12 & 0 & 0 & 0.53 & 0.03 & 3.01 & 0 & 0 & 0.68 & 0.09 & & $\mathrm{x}$ & $\mathrm{x}$ & $\mathrm{x}$ \\
\hline Geophagus brasiliensis & 2 & 2.03 & 0.41 & 0.14 & 2.42 & 0.58 & 0.05 & 3.24 & 0.1 & 0.62 & 0.67 & 0.32 & & & $\mathrm{x}$ & $\mathrm{x}$ \\
\hline Gymnotus aff. carapo & 10 & 1.52 & 0.1 & 0 & 0 & 0.6 & 0.01 & 1.36 & 0 & 0 & 0.71 & 0.11 & & $\mathrm{x}$ & $\mathrm{x}$ & $\mathrm{x}$ \\
\hline Hemigrammus marginatus & 10 & 2.69 & 0.3 & 0.13 & 2.59 & 0.53 & 0.03 & 3.95 & 0.13 & 4.43 & 0.55 & 0.27 & & & & $\mathrm{x}$ \\
\hline Hisonotus spp. & 10 & 0.67 & 0.15 & 0.31 & 2.18 & 0.58 & 0.04 & 2.07 & 0.1 & 2.26 & 0.65 & 0.24 & & $\mathrm{x}$ & $\mathrm{x}$ & \\
\hline Hoplias lacerdae & 6 & 1.36 & 0.22 & 0.17 & 2.82 & 0.61 & 0.06 & 1.88 & 0.18 & 0.21 & 0.66 & 0.29 & & $\mathrm{x}$ & $\mathrm{x}$ & $\mathrm{x}$ \\
\hline Hoplias malabaricus & 4 & 1.39 & 0.21 & 0.12 & 3.44 & 0.62 & 0.04 & 2.69 & 0.18 & 0.25 & 0.74 & 0.3 & & $\mathrm{x}$ & & $\mathrm{x}$ \\
\hline Hoplosternum littorale & 4 & 1.2 & 0.29 & 0.11 & 2.16 & 0.55 & 0.08 & 2.03 & 0.24 & 0.33 & 0.6 & 0.29 & & & $\mathrm{x}$ & $\mathrm{x}$ \\
\hline Hyphessobrycon micropterus & 6 & 3.16 & 0.37 & 0.12 & 2.89 & 0.47 & 0.02 & 3.59 & 0.14 & 3.42 & 0.55 & 0.28 & & & & $\mathrm{x}$ \\
\hline Hyphessobrycon santae & 10 & 2.96 & 0.34 & 0.11 & 2.49 & 0.53 & 0.03 & 3.31 & 0.11 & 3.95 & 0.55 & 0.27 & & & & $\mathrm{x}$ \\
\hline Hypostomus francisci & 10 & 0.74 & 0.21 & 0.35 & 1.37 & 0.61 & 0.12 & 2.11 & 0.25 & 0.33 & 0.71 & 0.23 & & $\mathrm{x}$ & $\mathrm{x}$ & $\mathrm{x}$ \\
\hline Hypostomus garmani & 10 & 0.68 & 0.19 & 0.34 & 1.36 & 0.6 & 0.1 & 2.1 & 0.18 & 0.36 & 0.73 & 0.22 & & $\mathrm{x}$ & $\mathrm{x}$ & $\mathrm{x}$ \\
\hline Hypostomus sp.3 & 4 & 0.72 & 0.21 & 0.31 & 1.8 & 0.64 & 0.14 & 1.92 & 0.27 & 0.3 & 0.69 & 0.23 & & $\mathrm{x}$ & $\mathrm{x}$ & $\mathrm{x}$ \\
\hline Imparfinis minutus & 7 & 0.8 & 0.13 & 0.21 & 2.21 & 0.43 & 0.07 & 1.97 & 0.11 & 2.62 & 0.64 & 0.22 & & $\mathrm{x}$ & $\mathrm{x}$ & $\mathrm{x}$ \\
\hline Leporinus piau & 2 & 1.77 & 0.33 & 0.12 & 2.5 & 0.59 & 0.03 & 2.4 & 0.11 & 0.67 & 0.64 & 0.26 & & & & $\mathrm{x}$ \\
\hline Leporinus reinhardti & 10 & 1.83 & 0.28 & 0.15 & 2.56 & 0.57 & 0.04 & 2.76 & 0.12 & 0.68 & 0.62 & 0.26 & & & $\mathrm{x}$ & $\mathrm{x}$ \\
\hline Leporinus taeniatus & 10 & 1.64 & 0.25 & 0.13 & 2.83 & 0.64 & 0.04 & 2.17 & 0.14 & 0.42 & 0.64 & 0.24 & & & $\mathrm{x}$ & $\mathrm{x}$ \\
\hline Lophiosilurus alexandri & 2 & 0.38 & 0.12 & 0.15 & 1.28 & 0.47 & 0.3 & 1.56 & 0.27 & 0.21 & 1.26 & 0.27 & & & $\mathrm{x}$ & $\mathrm{x}$ \\
\hline Moenkhausia costae & 10 & 2.96 & 0.34 & 0.11 & 2.72 & 0.55 & 0.02 & 4.53 & 0.14 & 2.51 & 0.61 & 0.27 & & & $\mathrm{x}$ & $\mathrm{x}$ \\
\hline Neoplecostomus franciscoensis & 10 & 0.62 & 0.16 & 0.29 & 1.12 & 0.54 & 0.06 & 1.5 & 0.1 & 2.04 & 0.71 & 0.27 & $\mathrm{x}$ & & & \\
\hline Orthospinus franciscensis & 10 & 4.34 & 0.5 & 0.12 & 2.9 & 0.62 & 0.01 & 4.61 & 0.09 & 2.48 & 0.62 & 0.28 & & & $\mathrm{x}$ & $\mathrm{x}$ \\
\hline Pachyurus francisci & 3 & 2.27 & 0.27 & 0.25 & 2.97 & 0.52 & 0.06 & 2.21 & 0.13 & 0.32 & 0.63 & 0.28 & & & & $\mathrm{x}$ \\
\hline Pamphorichthys hollandii & 2 & 1.52 & 0.27 & 0.37 & 2.29 & 0.56 & 0.05 & 2.33 & 0.2 & 3 & 0.57 & 0.25 & & & & $\mathrm{x}$ \\
\hline Phalloceros uai & 10 & 1.36 & 0.22 & 0.36 & 2.54 & 0.5 & 0.03 & 2.81 & 0.12 & 2.22 & 0.58 & 0.23 & & $\mathrm{x}$ & & $\mathrm{x}$ \\
\hline Piabina argentea & 10 & 2.53 & 0.23 & 0.15 & 4.57 & 0.5 & 0.03 & 3.91 & 0.12 & 3.34 & 0.57 & 0.26 & & $\mathrm{x}$ & $\mathrm{x}$ & $\mathrm{x}$ \\
\hline Pimelodus fur & 3 & 1.41 & 0.24 & 0.16 & 2.47 & 0.56 & 0.06 & 1.99 & 0.15 & 0.83 & 0.73 & 0.28 & & & $\mathrm{x}$ & $\mathrm{x}$ \\
\hline Pimelodus maculatus & 10 & 1.36 & 0.24 & 0.16 & 2.27 & 0.57 & 0.08 & 2.27 & 0.19 & 0.57 & 0.69 & 0.27 & & & $\mathrm{x}$ & $\mathrm{x}$ \\
\hline Pimelodus pohli & 10 & 1.4 & 0.23 & 0.16 & 2.07 & 0.54 & 0.03 & 2.28 & 0.19 & 0.56 & 0.68 & 0.26 & & & & $\mathrm{x}$ \\
\hline Prochilodus argenteus & 10 & 2.38 & 0.38 & 0.17 & 2.84 & 0.56 & 0.03 & 3.37 & 0.16 & 0.38 & 0.56 & 0.28 & & & $\mathrm{x}$ & $\mathrm{x}$ \\
\hline Prochilodus costatus & 10 & 2.38 & 0.38 & 0.17 & 2.84 & 0.56 & 0.03 & 3.37 & 0.16 & 0.38 & 0.56 & 0.28 & & & $\mathrm{x}$ & $\mathrm{x}$ \\
\hline Psellogrammus kennedyi & 10 & 4.01 & 0.43 & 0.1 & 3.61 & 0.54 & 0.02 & 3.75 & 0.14 & 2.23 & 0.56 & 0.27 & & & $\mathrm{x}$ & $\mathrm{x}$ \\
\hline Pterygoplichthys etentaculatus & 2 & 0.85 & 0.27 & 0.3 & 1.02 & 0.51 & 0.15 & 2.21 & 0.21 & 0.35 & 0.64 & 0.26 & & & & $\mathrm{x}$ \\
\hline Pygocentrus piraya & 10 & 2.95 & 0.5 & 0.13 & 2.27 & 0.57 & 0.03 & 2.32 & 0.16 & 0.4 & 0.61 & 0.35 & & & $\mathrm{x}$ & $\mathrm{x}$ \\
\hline Rhamdia quelen & 2 & 0.99 & 0.19 & 0.2 & 2.7 & 0.5 & 0.08 & 1.52 & 0.21 & 0.73 & 0.67 & 0.25 & & $\mathrm{x}$ & $\mathrm{x}$ & \\
\hline Rineloricaria sp.N & 7 & 0.6 & 0.1 & 0.52 & 0.48 & 0.55 & 0.16 & 2.13 & 0.07 & 1.64 & 0.7 & 0.16 & & $\mathrm{x}$ & & \\
\hline Roeboides xenodon & 10 & 4.1 & 0.38 & 0.09 & 3.79 & 0.53 & 0.03 & 3.59 & 0.13 & 1.67 & 0.59 & 0.28 & & & & $\mathrm{x}$ \\
\hline Salminus franciscanus & 10 & 2.05 & 0.24 & 0.15 & 2.37 & 0.57 & 0.04 & 3.01 & 0.14 & 0.42 & 0.7 & 0.27 & & & $\mathrm{x}$ & $\mathrm{x}$ \\
\hline Salminus hilarii & 3 & 2.06 & 0.26 & 0.14 & 2.35 & 0.59 & 0.04 & 3.42 & 0.16 & 0.38 & 0.63 & 0.28 & & & $\mathrm{x}$ & $\mathrm{x}$ \\
\hline Schizodon knerii & 10 & 1.86 & 0.27 & 0.15 & 2.73 & 0.6 & 0.02 & 2.46 & 0.13 & 0.44 & 0.58 & 0.22 & & & $\mathrm{x}$ & $\mathrm{x}$ \\
\hline Serrapinnus heterodon & 10 & 2.83 & 0.29 & 0.14 & 2.95 & 0.51 & 0.02 & 3.99 & 0.12 & 3.73 & 0.57 & 0.24 & & & & $\mathrm{x}$ \\
\hline Serrapinnus piaba & 10 & 2.54 & 0.29 & 0.15 & 2.53 & 0.54 & 0.03 & 3.44 & 0.12 & 4.73 & 0.54 & 0.24 & & $\mathrm{x}$ & & $\mathrm{x}$ \\
\hline Serrasalmus brandtii & 10 & 3.79 & 0.52 & 0.1 & 2.23 & 0.51 & 0.01 & 3.06 & 0.13 & 0.8 & 0.66 & 0.35 & & & $\mathrm{x}$ & $\mathrm{x}$ \\
\hline Stegophilus insidiosus & 10 & 0.6 & 0.09 & 0.16 & 3.13 & 0.47 & 0.04 & 2.74 & 0.06 & 3.37 & 1 & 0.16 & & & $\mathrm{x}$ & $\mathrm{x}$ \\
\hline Steindachnerina elegans & 10 & 2 & 0.29 & 0.16 & 3.16 & 0.59 & 0.02 & 2.89 & 0.11 & 1.41 & 0.67 & 0.26 & & & $\mathrm{x}$ & $\mathrm{x}$ \\
\hline Synbranchus marmoratus & 2 & 1.14 & 0.04 & 0 & 0 & 0.57 & 0 & 0 & 0 & 0 & 0.64 & 0.08 & & & & $\mathrm{x}$ \\
\hline Tetragonopterus chalceus & 10 & 3.47 & 0.51 & 0.1 & 3.8 & 0.56 & 0.03 & 5.04 & 0.11 & 1.49 & 0.6 & 0.29 & & & & $\mathrm{x}$ \\
\hline Trachelyopterus galeatus & 10 & 1.39 & 0.27 & 0.11 & 4.05 & 0.58 & 0.05 & 2.56 & 0.15 & 0.66 & 0.6 & 0.26 & & & & $\mathrm{x}$ \\
\hline Trichomycterus $\mathrm{cf}$. alternatus & 7 & 1 & 0.18 & 0.23 & 2.65 & 0.44 & 0.1 & 1.61 & 0.13 & 1.93 & 0.87 & 0.2 & & $\mathrm{x}$ & & \\
\hline Trichomycterus reinhardti & 2 & 3 & 0.35 & 0.1 & 3.53 & 0.6 & 0.04 & 3.57 & 0.09 & 1.06 & 0.61 & 0.27 & $\mathrm{x}$ & & & \\
\hline Trichomycterus sp. & 4 & 0.78 & 0.14 & 0.24 & 2.79 & 0.45 & 0.06 & 1.85 & 0.11 & 2.5 & 0.8 & 0.18 & & $\mathrm{x}$ & & \\
\hline Triportheus guentheri & 10 & 3 & 0.36 & 0.1 & 3.55 & 0.61 & 0.04 & 3.87 & 0.09 & 0.79 & 0.62 & 0.27 & & & $\mathrm{x}$ & $\mathrm{x}$ \\
\hline
\end{tabular}



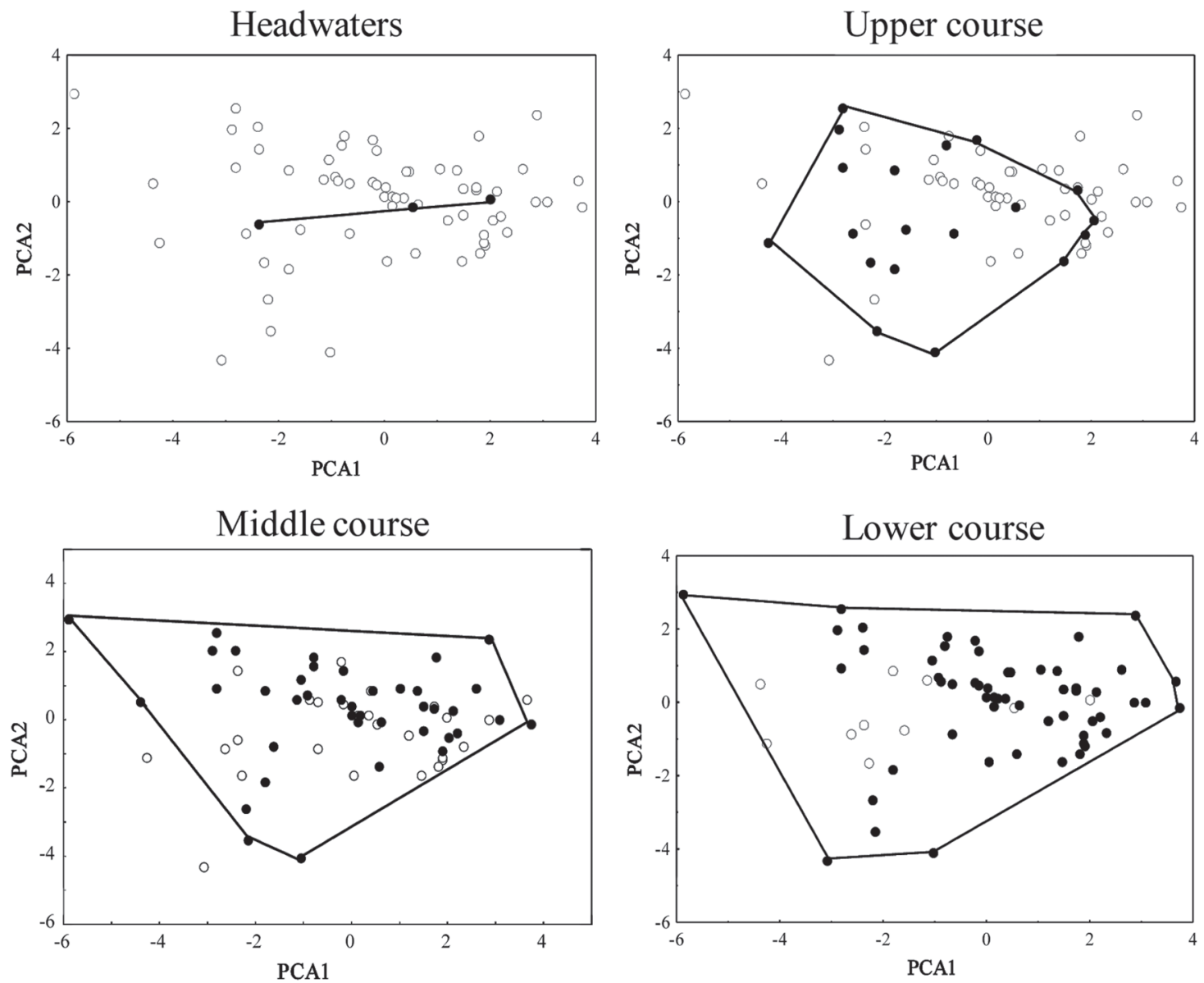

Fig. 2. Projection of the first two principal components based on 11 fish morphological attributes for the headwaters, upper course, middle course and lower course of the rio das Velhas.

point out that only three species were registered in the headwaters, a richness that could be not enough to allow comparisons based on attributes such as species dispersion in morphological space and distances to the centroid.

Table 2. Contribution of morphological attributes to the first two PCA axes measured for 67 fish species in the rio das Velhas Basin. Numbers in bold represent scores with higher contribution for the observed variance.

\begin{tabular}{lcc}
\hline Attributes & CP1 & CP2 \\
\hline CI & $\mathbf{0 . 9 1}$ & -0.11 \\
RD & $\mathbf{0 . 8 4}$ & 0.37 \\
RCPL & -0.49 & 0.2 \\
CPCI & $\mathbf{0 . 6 6}$ & 0.32 \\
IVF & 0.09 & 0.36 \\
RPFA & $\mathbf{- 0 . 7}$ & 0.42 \\
PFAR & $\mathbf{0 . 8 3}$ & -0.01 \\
RCFA & -0.22 & $\mathbf{0 . 8 2}$ \\
CFAR & 0.27 & -0.45 \\
REP & $\mathbf{- 0 . 6 9}$ & 0.18 \\
RHL & 0.52 & $\mathbf{0 . 7 3}$ \\
\hline Variance (\%) & $\mathbf{3 8 . 7 7}$ & $\mathbf{1 8 . 5 1}$ \\
\hline Total variance (\%) & \multicolumn{3}{c}{$\mathbf{5 7 . 2 8}$} \\
\hline
\end{tabular}

Headwaters species, represented by Astyanax aff. scabripinnis, Neoplecostomus franciscoensis and Trichomycterus reinhardti, showed the mean attribute values that most contributed to the variation of the first two PCA axes. Each of those species features a different body morphology: Astyanax aff. scabripinnis, laterally flat, dorso-ventrally tall, with compressed caudal peduncle, typical of nektonic species; Neoplecostomus franciscoensis shows depressed body shape, characterized by dorso-ventral flattening and dorsally located eyes, common in benthonic species; Trichomycterus reinhardti has cylindrical body, dorsal eyes and the largest pectoral fins of all the species in question, fitting into nektobenthonic species (Casatti et al., 2001). These types represent a morphological patterns common to all four reaches.

The three above mentioned species are typical of headwaters regions, which have higher declivity and flow speeds. These regions normally feature areas rich in different types of food arranged in spots, as well as abundant shelter among the different substrates, such as coarse sand, gravel and rocks (Casatti \& Castro, 2006). Headwaters regions are naturally characterized by a wide range of water and environment conditions, reflecting on the associated 

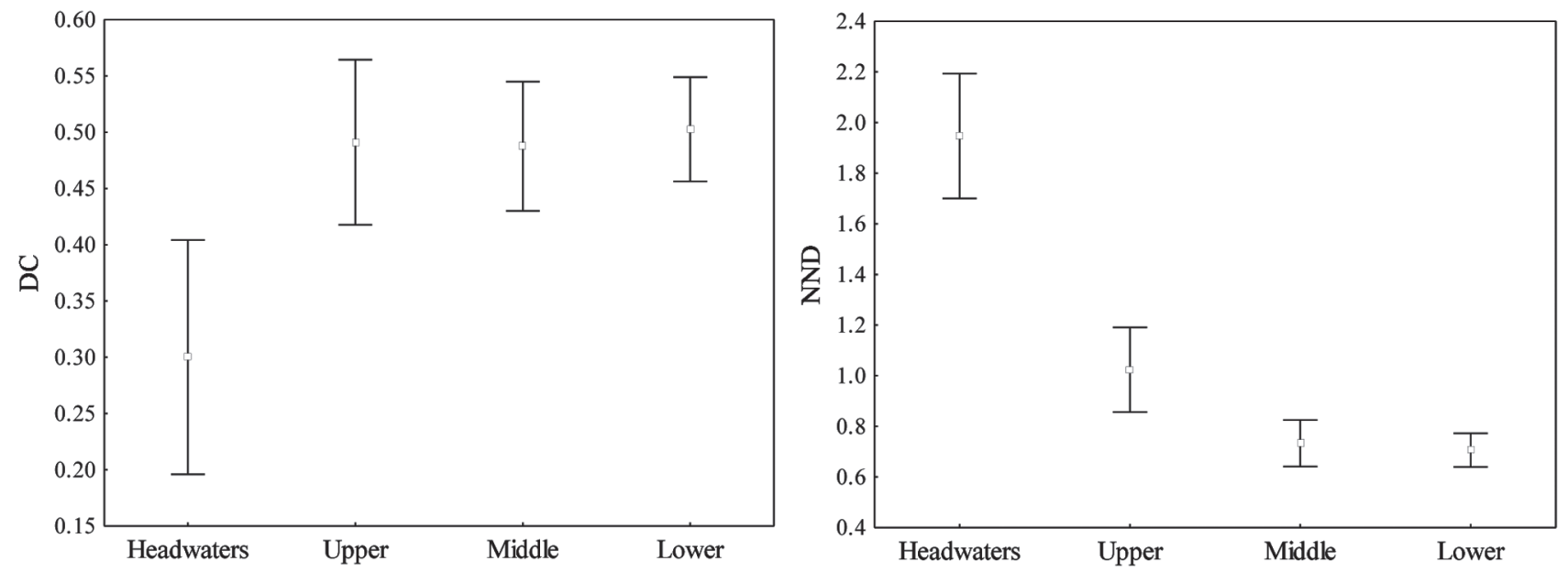

Fig. 3. Box plots of distance to the centroid (DC) and distance of each species to the nearest neighbor (NND) for headwaters, upper course, middle course and lower course of the rio das Velhas, with their respective means and standard errors.

ichthyofauna, which shows specific adaptations (ex. morphological, reproductive, trophic) to such ecologically unstable conditions (Weitzman et al., 1996). The fish assemblage from hydrologically variable streams, like headwaters, is characterized by small-sized species, with generalized feeding strategies, associated with general substrate and tolerant to silt, reflecting a range of fish morphologies adapted to these conditions (Poff, 1995). The natural features and conditions, combined with biogeographical issues and the small area, would justify the low density of morphological types in the rio das Velhas headwaters region.

The species composition in the upper course also differs from the other reaches. The predominant morphological characteristics are depressed bodies, dorsally located eyes, and large pectoral and caudal fins. According to Casatti \& Castro (2006), those traits are associated with high hydrodynamism, which is common in the upper courses of rivers. It is noteworthy that this reach features evidence of intense pollution and siltation, as it receives domestic and industrial waste from the Belo Horizonte metropolitan area (RMBH). For this reason, it would be interesting to test whether it presents a more simplified ichthyofauna in terms of morphological types, with the absence of more specialized body forms, or there is a pattern in fish ecomorphology regarding this and other preserved reaches with the same comparable size in rio das Velhas basin.

Starting in the upper course, species Gymnotus aff. carapo, Eigenmannia virescens, and Synbranchus marmoratus were observed as well. These species have peculiar characteristics, different from the body types found elsewhere in our work, namely absent or poorly developed fins. As such, these species would be better adapted in lentic and structured environments ( $e g$, grassy banks for shelter against predators and foraging), found in larger reaches.

The intense morphological overlap found in middle and low course reaches, as well as the high richness, may be manifestations of the similar environmental characteristics and width between the two areas. According to Williams (1964), area increases lead to greater habitat heterogeneity, enabling an increase in the number of available niches to support a greater number of species, and consequently, different morphologies (Winemiller, 1991). The high density of morphological types in these regions, if compared to the headwaters and upper course, leads to the assumption that there is great resource availability at those sites, and therefore the fish assemblages were being more intensely regulated by biotic (ex., competition) than abiotic factors.

According to the results, the functional aspects of the ichthyofauna, which reflect the morphological attributes of species, would be similar along the longitudinal gradient of the rio das Velhas, as the morphological spaces were the same for the different studied reaches. Therefore, in order to use functional groups as decision-making tools for the conservation and revitalization of the rio das Velhas, it is necessary to analyze the species density within those groups, as well as their composition.

\section{Acknowledgements}

We wish to thank CNPq through the CT-Hidro program (Process number: 555698/2006-8), Projeto Manuelzão, FundoFundep, Fundação O Boticário, Copasa, Fapemig, and Feam for financial support; Nuvelhas for logistical support; Sarah Saraiva and Suellen Zatti for helping with the morphometric measurements; Daniel Nascimento Rodrigues for the basin map.

\section{Literature Cited}

Angermeier, P. L. \& J. R. Karr. 1983. Fish communities along environmental gradients in a system of tropical streams. Environmental Biology of Fishes, 9: 117-135.

Belliard, J., P. Böet \& E. Tales. 1997. Regional and longitudinal patterns of fish community structure in the Seine River basin, France. Environmental Biology of Fishes, 50: 133-147. 
Bistoni, M. A. \& A. C. Hued. 2002. Patterns of fish species richness in rivers of the central region of Argentina. Brazilian Journal of Biology, 62: 753-764.

Casatti, L. \& R. M. C. Castro. 2006. Testing the ecomorphological hypothesis in a headwater riffles fish assemblage of the Rio São Francisco, southeastern Brazil. Neotropical Ichthyology, 4: 203214.

Casatti, L., F. Langeani \& R. M. C. Castro. 2001. Peixes de riacho do Parque Estadual Morro do Diabo, bacia do alto rio Paraná, SP. Biota Neotropica, 1: 1-15.

CETEC. 1983. Diagnóstico Ambiental do Estado de Minas Gerais. Fundação Centro Tecnológico de Minas Gerais/CETEC. Série de Publicações Técnicas/SPT-010, 158p.

Fausch, K. D., J. R. Karr \& P. R. Yant. 1984. Regional application of an index of biotic integrity based on stream fish communities. Transactions of the American Fisheries Society, 113: 39-55.

Ferreira, K. M. 2007. Biology and ecomorphology of stream fishes from the rio Mogi-Guaçu basin, Southeastern Brazil. Neotropical Ichthyology, 5: 311-326.

Gatz Jr., A. J. 1979a. Community organization in fishes as indicated by morphological features. Ecology, 60: 711-718.

Gatz Jr., A. J. 1979b. Ecological morphology of freshwater stream fishes. Tulane Studies in Zoology and Botany, 21:91-124.

Gorman, O. T. \& J. R. Karr. 1978. Habitat structure and stream fish communities. Ecology, 59: 507-515.

Helfman, G. S., B. B. Collette, D. E. Facey \& B. W. Bowen. 2009. The diversity of fishes: Biology, Evolution, and Ecology. West Sussex, Wiley-Blackwell, 720 p.

Hugueny, B. \& M. Pouilly. 1999. Morphological correlates of diet in an assemblage of West African freshwater fishes. Journal of Fish Biology, 54: 1310-1325.

Ibanez, C., T. Oberdorff, G. Teugels, V. Momononekene, S. Lavoué, Y. Fermon, D. Paugy \& A. Kamdem Toham. 2007. Fish assemblages structure and function along environmental gradients in rivers of Gabon (Africa). Ecology of Freshwater Fish, 16: 315-334.

IBGE, Instituto Brasileiro de Geografia e Estatítica. 2000. Sinopse preliminar do censo demográfico. Rio de Janeiro, IBGE, 450p.

Infante, D. \& D. Allan. 2010. The response of stream fish assemblages to local-scale habitat as influenced by landscape: a mechanistic investigation of stream fish assemblages. Pp. 371397. In: Jackson, D. A. \& K. B. Gido (Eds.). Community ecology of stream fishes: concepts, approaches and techniques. American Fisheries Society, Symposium 73, Bethesda, Maryland, 684p.

Karr, J. R. \& F. C. James. 1975. Eco-morphological configurations and convergent evolution in species and communities. Pp. 258291. In: Cody, M. L. \& J. M. Diamond (Eds.). Ecology and evolution of communities. Cambridge, The Belknap Press of Harvard University, 545p.

Keast, A. \& D. Webb. 1966. Mouth and body form relative to feeding ecology in the fish fauna of a small lake, Lake Opinicon, Ontario. Journal of the Fisheries Research Board of Canada, 23: 1845-1874.

Kennard, M. J., J. D. Olden, A. H. Arthington, B. J. Pusey \& N. L. Poff. 2007. Flow regime and habitat interact at multiple scales to shape fish assemblages in hydrologically variable rivers of eastern Australia. Canadian Journal of Fisheries and Aquatic Sciences, 64: 1346-1259.

Lowe-McConnell, R. H. 1987. Ecological studies in tropical fish communities. London, Cambridge University Press, 382p.

Matthews, W. J. 1998. Patterns in Freshwater Fish Ecology. New York, Chapman and Hall, 757p.
McGarvey, D. J. \& R. M. Hughes. 2008. Longitudinal zonation of Pacific Northwest (U.S.A.) fish assemblages and the species discharge relationship. Copeia, 2008: 311-321.

Mouillot, D., S. Spatharis, S. Reizopoulou, T. Laugier, L. Sabetta, A. Basset \& T. Do Chi. 2006. Alternatives to taxonomic-based approaches to assess changes in transitional water communities. Aquatic Conservation: Marine and Freshwater Ecosystems, 16: 469-482.

Oberdorff, T. \& J. P. Percher. 1992. Fish assemblage structure and stability in Brittany streams (France). Aquatic Living Resource, 5: 215-223.

Oliveira, E. F., E. Goulart, L. Breda, C. V. Minte-Vera, L. R. S. Paiva \& M.R. Vismara. 2010. Ecomorphological patterns of the fish assemblage in a tropical floodplain: effects of trophic, spatial and phylogenetic structures. Neotropical Ichthyology, 8: 569586.

Peterson, J. T. \& C. F. Rabeni, 2001. The relation of fish assemblages to channel units in an Ozark stream. Transactions of the American Fisheries Society, 130: 911-926.

Pianka, E. R. 1994. Evolutionary ecology. New York, Harper Collins, $397 p$.

Pompeu, P. S., C. B. M. Alves \& M. Callisto. 2005. The effects of urbanization on biodiversity and water quality in the Rio das Velhas basin, Brazil. American Fisheries Society Symposium, 47: 11-22.

Poff, N. L. \& J. D. Allan. 1995. Functional organization of stream fish assemblages in relation to hydrologic variability. Ecology, 76: 606-627.

Ricklefs, R. E., D. Cochran \& E. R. Pianka. 1981. A morphological analysis of the structure of communities of lizards in desert habitats. Ecology, 62: 1474-1483.

Statistica Software, 2001. Statistica for Windows - computer program manual. Tulsa, Statsoft.

Tonn, W. M., J. J. Magnuson, M. Rask \& J. Toivonen. 1990. Intercontinental comparison of small-lake fish assemblages: the balance between local and regional processes. American Naturalist, 136: 345-375.

Vannote, R. L., G. W. Minshall, K. W. Cummins, J. R. Sedell \& C. E. Cushing. 1980. The river continuum concept. Canadian Journal of Fisheries and Aquatic Sciences, 37: 130-137.

Watson, D. J. \& E. K. Balon. 1984. Ecomorphological analysis of taxocenes in rainforest streams of northern Borneo. Journal of Fish Biology, 25: 371-384.

Weitzman, S. H., L. Palmer, N. A. Menezes \& J. R. Burns. 1996. Maintaining tropical and subtropical forest-adapted fishes (especially the species of Mimagoniates) (part 1). Tropical Fish Hobbyist, 44: 184-194.

Willis, S. C., K. O. Winemiller \& H. Lopez-Fernandez. 2005. Habitat structural complexity and morphological diversity of fish assemblages in a Neotropical floodplain river. Oecologia, 142: 284-295.

Winemiller, K. O. 1991. Ecomorphological diversification in lowland freshwater fish assemblages from five biotic regions. Ecological Monographs, 61: 343-365.

Zobel, M. 1997. The relative role of species pools in determining plant species richness: An alternative explanation of species coexistence? Trends in Ecology and Evolution, 12: 266-269.

Submitted October 31, 2011 Accepted March 9, 2012 Published June 29, 2012 